\title{
Phenotypic correlation and regression of hydroponics maize fodder as influenced by seed rate, nutrient sources and spray schedule
}

\author{
Santosh Nagappa Ningoji 约 \\ Department of Agronomy, College of Agriculture, University of Agricultural Sciences, GKVK, Bengaluru \\ Thimmegowda, M. N. \\ AICRP for Dry land Agriculture, University of Agricultural Sciences, GKVK, Bengaluru
}

\begin{tabular}{|c|c|}
\hline ARTICLE INFO & ABSTRACT \\
\hline $\begin{array}{l}\text { Received : 04 July } 2021 \\
\text { Revised : } 22 \text { August } 2021 \\
\text { Accepted : } 30 \text { August } 2021 \\
\text { Available online: } 9 \text { December } 2021 \\
\text { Key Words: } \\
\text { Correlation } \\
\text { Foliar spray } \\
\text { Fresh fodder yield } \\
\text { Regression } \\
\text { Seed rate }\end{array}$ & 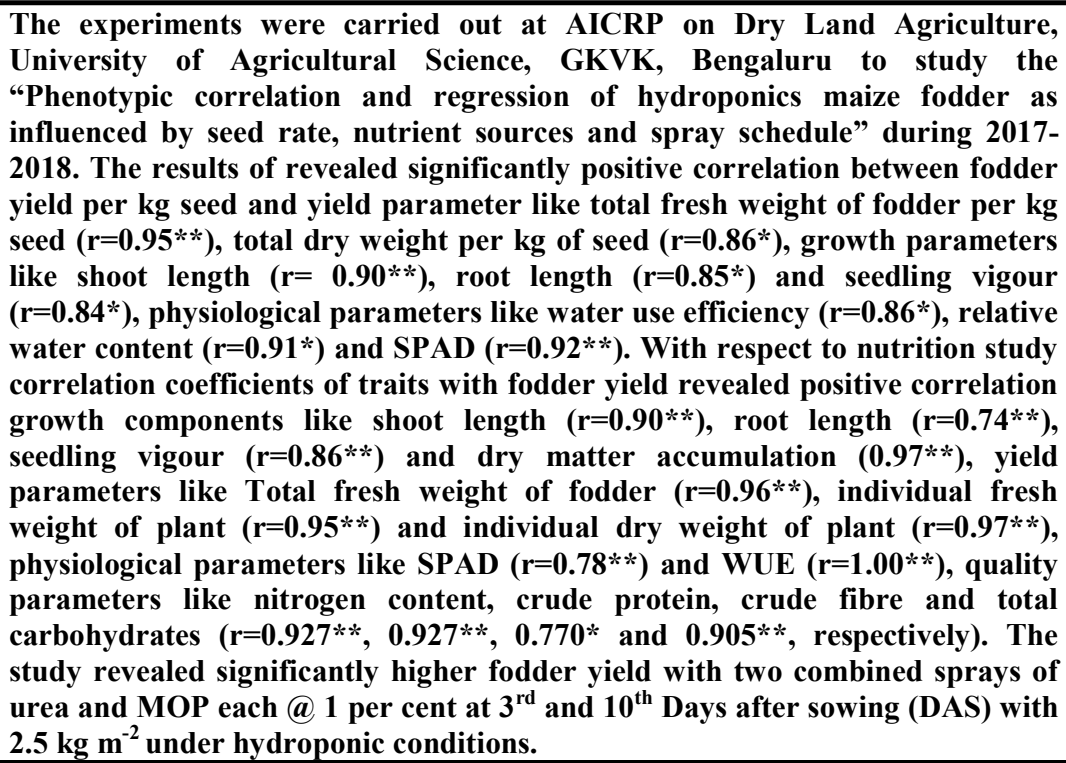 \\
\hline
\end{tabular}

\section{Introduction}

Small and marginal farmers in India rely heavily on livestock for their nutritional and livelihood stability. The total livestock population in the country is 512.06 million, down 3.33 percent from the previous census due to a lack of feed/fodder supply. However, the number of milch animals (milching and dry) has increased by 6.75 percent, from 111.09 million to 118.59 million (Anon, 2017). The country's expanding cattle population necessitates more fodder. Reduced livestock productivity is caused by a lack of fodder, water due to unpredictable rainfall distribution, and land allotment for green fodder cultivation.

Green fodder is the most important part of a livestock's diet. Green fodder deficiency has a direct impact on animal reproductive and productivity. The lack of area for fodder growing is one of the key obstacles linked with the traditional method of green fodder production (Naik et al., 2013). Due to a lack of water and recurrent droughts, India has had a feed crisis for livestock in recent years. As a result, hydroponic technology can improve water usage efficiency and productivity when water resources are limited. Vitamins, minerals, enzymes, and 85 to $90 \%$ digestible protein are abundant in hydroponically cultivated fodders. Sprouting grains enhances enzymatic activity, total protein, amino acid profile alterations, sugars, crude fibre, some vitamins and minerals, and decreases starch (Lorenz, 1980).

Maize is an essential crop with a wide range of applications. Due to its increased fresh biomass, it 
is also employed as fodder in addition to grain consumption. Because of its availability, lower seed cost, higher biomass production, greater seed to biomass ratio, and faster growth habit, maize is a preferable choice for hydroponic fodder production (Naik et al., 2012). Optimum seed rate and nutrition are the most important parts of agro-techniques, as they are linked to production, profitability, and quality. Nutrition is a critical key component that influences crop growth and development, as well as crop production. For optimal dry matter formation, these nutrients must be present in specific proportions. Nitrogen is a vital primary nutrient that helps to increase vegetative biomass, which is required for fodder yield. Because it is a component of crude protein, it is also significant in the nutritional quality of fodder. Potassium is the third most important macronutrient, and it is required for a variety of physiological processes such as protein synthesis, enzyme activity, ionic balance, and osmoregulation. Crop yield quality and shelf life are also improved. Under a hydroponic production method, nutrient supplementation according to crop demands involves times of application and nutrition source. As a result, during 2017-2018, at AICRP for Dry Land Agriculture, UAS, GKVK, Bengaluru, an experiment on "Phenotypic correlation and regression of hydroponics maize fodder as influenced by seed rate, nutrient sources, and spray schedule" was undertaken.

\section{Material and Methods \\ Experimental Site}

The experiments were conducted at the AICRP for Dry Land Agriculture, University of Agricultural Science, GKVK, Bengaluru situated in the Eastern Dry Zone of Karnataka, India at $12^{0} 58^{\prime} \mathrm{N}$ latitude and $75^{\circ} 35^{\prime} \mathrm{E}$ longitude with at an altitude of 930 meter above mean sea level.

\section{Experimental details}

The studies were carried out objectively in two batches at the hydroponic facility of the AICRP for Dry Land Agriculture, UAS, GKVK, Bengaluru, and the best treatment of both experiments was chosen for demonstration. The first experiment used a completely randomised design (CRD) with five repeats and six seed rate treatments of 1.50 , $1.75,2.00,2.25,2.50$, and $2.75 \mathrm{~kg} \mathrm{~m}^{-2}$ to standardise the optimum seed rate. The second experiment used the optimal seed rate treatment to standardise nutrient source and spraying schedule $\left(2.5 \mathrm{~kg} \mathrm{~m}^{-2}\right)$. The Nutrition experiment was set up using a Completely Randomized Design with factorial concept in three repetitions having four different nutrient sources (urea@1\%,MOP@1 \%, urea and MOP each@1\% and 19:19:19@1 $\%$ ) and 2 levels of spray schedules (one spray at 6 DAS and two sprays at 3 and 10 DAS), as well as no nutrient spray as a control.

\section{Hydroponic unit}

The hydroponic unit was constructed with iron angles having a length of $325 \mathrm{~cm}$, a width of 170 $\mathrm{cm}$ and a height of $220 \mathrm{~cm}$. It holds 30 trays, made with vinyl fibre of dimensions $2.5 \times 1.5 \times 0.15 \mathrm{ft}$. Iron angles with a length of $325 \mathrm{~cm}$, a width of 170 $\mathrm{cm}$, and a height of $220 \mathrm{~cm}$ were used to construct the hydroponic unit. It has 30 trays and is composed of vinyl fibre with dimensions of $2.5 \times$ $1.5 \times 0.15 \mathrm{ft}$. The iron angles are provided on one side of the tray holder to allow the tray to align in a slanting position, preventing excess water from stagnating. The water was pumped from the tank by automated equipment with a pumping engine, and drip laterals with foggers were sprayed on each tray. The automation device was programmed to spray water for a minute every two hours.

\section{Production of hydroponic fodder maize}

Maize seeds are steeped in water for a day before being incubated in gunny cloth bags for germination. The germinated seeds were spread on trays according to the treatment (dry seed weight) and grown for 14 days. In the study, automated fogging was used, with the automation set to one minute every two hours intervals. After standardising seed rate in the first trial, the optimal treatment of $2.5 \mathrm{~kg} \mathrm{~m}^{-2}$ was chosen as the seed rate for hydroponic fodder maize feeding. Urea, MOP and 19:19:19 are among the water-soluble fertilisers utilised in the foliar spray. In the study, one gram of water soluble fertiliser was dissolved in $100 \mathrm{~mL}$ of water and made into a $1 \%$ solution. On 3 DAS, 6 DAS, and 10 DAS, $100 \mathrm{~mL}$ of $1 \%$ fertiliser solution was sprayed with a hand sprayer on each tray according to the treatment schedule. Each treatment's fodder was harvested on the $14^{\text {th }}$ day, converted to metre base, and expressed as $\mathrm{kg}$ $\mathrm{m}^{-2}$.

\section{Data collection}

At harvest, five plants were randomly selected from each treatment to record data on growth parameters 
such as shoot length, root length, seedling vigour, and dry matter accumulation. Harvest samples were used to record yield attributes. The samples were selected at random and dried in the shade before drying in oven at $60^{\circ} \mathrm{C}$ until they reached a constant weight. The dry matter yield of green fodder maize was then calculated $\left(\mathrm{kg} \mathrm{m}^{-2}\right)$. Dried samples were also processed using an electrically operated grinding mill to pass through a $1 \mathrm{~mm}$ filter and stored for measurement of quality parameters such as crude protein, crude fibre, and total carbs using the AOAC standard method (2000). Data pertaining to physiological characteristics such as SPAD, water usage efficiency, and relative water content were noted. Throughout the experiment, the total water added and drained from each tray was recorded to calculate total water use and water use efficiency. Total amount of water utilised by plants (litres per tray) is estimated using the equation below (Al Ajmi et al., 2009)

Total water use $=$ Total added water in irrigation Total drained water out of trays.

Water use efficiency (WUE) in $\mathrm{kg}$ fresh weight $\mathrm{m}^{-3}$ water was computed according to the equation:

$$
\begin{aligned}
& \text { WUE } \\
& \left.\mathrm{m}^{-3}\right)
\end{aligned} \quad\left(\mathrm{kg}=\frac{\begin{array}{l}
\text { Total green fodder } \\
\text { produced }(\mathrm{kg})
\end{array}}{\text { Total water used (liter) }} \times 1000\right.
$$

\section{Statistical analysis}

According to Gomez \& Gomez, the experimental data obtained on various plant development and yield components were subjected to Fisher's method of "Analysis of variance" (ANOVA) (1984). When the F-test revealed a significant difference between the treatment means, an acceptable value of critical differences (CD) was calculated. At a $0.01 \%$ and $0.05 \%$ probability level, the results are given and discussed. To investigate the relationship between fodder yield and various growth, yield, physiological and nutrition factors a correlation matrix was created. According to Sendecor and Cochran (1989), simple linear regression was used to calculate the coefficient of determination for fodder yield with various growth, yield, physiological, and nutrition characteristics. Stepwise multiple linear regression analysis to find the best variables that accounted for the largest variance in maize fodder yield Draper and Smith (1998). The coefficient of determination $\left(R^{2}\right)$ was used to calculate the relative contribution.
Finally, Statistical Package for Social Science, version 27 was used to do statistical analysis (SPSS, 2020). In the seed rate experiment, the dependent factors were fodder yield per $\mathrm{kg}$ and fodder yield per square metre in nutrition.

\section{Results and Discussion}

\section{Experiment 1: Standardization of seed rate for} hydroponic production of fodder maize

Yield is the resultant of many metabolic activities occurring at various stages of plant development. The crop's fodder output is influenced by both external and internal variables. The variables include growth parameters (shoot length, root length, seedling vigour and dry matter accumulation) at different growth stages and yield parameters (fresh weight and dry weight) at harvest. The results revealed that $2.75 \mathrm{~kg} \mathrm{~m}^{-2}$ seed rate has recorded significantly higher fresh fodder maize yield as compared to $1.50 \mathrm{~kg} \mathrm{~m}^{-2}$ and it was on par with $2.5 \mathrm{~kg} \mathrm{~m}^{-2}$ seed rate. Even though the fodder yield was higher with $2.75 \mathrm{~kg} \mathrm{~m}^{-2}$ seed rate, the yield per $\mathrm{kg}$ of seed was higher with $2.5 \mathrm{~kg} \mathrm{~m}^{-2}$ seed rate (Figure 1). As a result, the optimum seed rate for productive hydroponic fodder maize production was determined to be $2.5 \mathrm{~kg} \mathrm{~m}^{-2}$. Higher seed rate increased fresh green yield of barley and maize (El-Morsy et al., 2013; Naik et al., 2017).

\section{Correlation analysis}

It's crucial to understand the relationship between fodder yield and other growth and yield characteristics when deciding on the best seed rate in any experiment. As a result, attempts were made to assess various correlations and interactions between yield and other variables. To establish a correct link with fodder yield per $\mathrm{kg}$ of seeds sowed, growth, yield, physiological, nutrient uptake, and quality criteria were considered. Table 1 shows the coefficients of association between fodder yield and other variables.

The relationship between fodder yield and yield attributing parameters revealed that total fresh weight $\left(\mathrm{r}=0.86^{*}\right)$, total fresh weight per $\mathrm{kg}$ seed $\left(\mathrm{r}=0.95^{* *}\right)$, and total dry weight $\left(\mathrm{r}=0.82^{*}\right)$ had the highest significant positive correlation with fodder yield per $\mathrm{kg}$ of seeds sown, indicating that yield is dependent on these parameters. This means that increasing the value of one of these parameters causes the value of the other parameter with which 


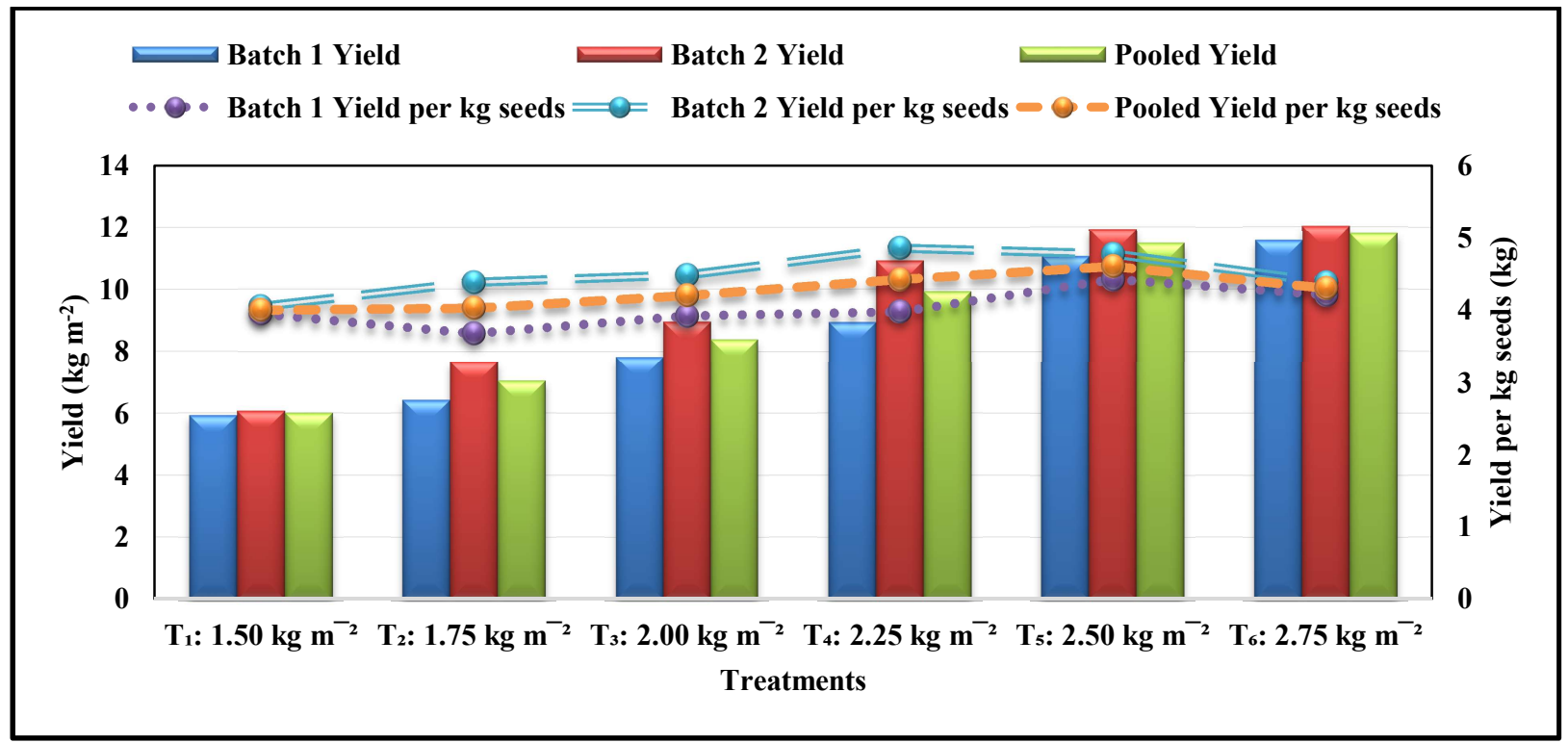

Figure 1: Yield and yield per kg seed of fodder maize as influenced by seed rate under hydroponics

it is substantially associated to increase. In addition, the variables are positively correlated at $p<0.05$. Increased seed rate resulted in a considerable increase in green fodder production per $\mathrm{kg}$ seeds due to an increase in plant population. Greater yield characteristics including fresh weight of shoot, root, and seed, as well as total dry matter accumulation in shoot, root, and seed, are responsible for the higher green fodder yield (El-Morsy et al., 2013; Naik et al., 2017). The dry matter accumulation per $\mathrm{kg}$ seeds increased with increased seed rate up to $2.50 \mathrm{~kg} \mathrm{~m}^{-2}$ thereafter it was reduced at $2.75 \mathrm{~kg} \mathrm{~m}^{-2}$, it is mainly due to competition between seedlings for growth resources viz., space, light and water etc. Further, higher seed rate than optimum also encourages the growth of fungus and hinders the accumulation of dry matter. This is in conformity with Massantini and Magnani (1980). The parameters like total fresh weight per plant $(\mathrm{g})$ and total dry weight were negatively correlated $(\mathrm{r}=-0.54$ and -0.67 , respectively) with fodder yield per $\mathrm{kg}$ seeds. The relatively larger fresh and dry weights of seedlings were attributed to a greater quantity of dry matter partitioning to different sections of the seedling at various stages of growth for each plant. As a result of the lower seed rate, the individual fresh and dry weight per plant was higher.

The correlation coefficients of growth parameters viz., shoot length $\left(\mathrm{r}=0.90^{*}\right)$, root length $\left(\mathrm{r}=0.85^{*}\right)$ and seedling vigour $\left(\mathrm{r}=0.84^{*}\right)$ have significant positive correlation with fodder yield per $\mathrm{kg}$ seed
(Table 1). Since plant growth is assessed in terms of rate of dry matter production and partitioning into distinct plant sections, which ultimately reflects on economic yield, because it is a result of multiple physiological and biological processes. In this manner, the grains serve as a source of dry matter production and the vegetative plant parts as a sink for dry matter accumulation. In fodder maize, vegetative part is the source and sinks in the view of photosynthetic area and assimilation in the stem as it forms the economical part. As a result, growth characteristics are crucial in terms of economic yield. The physiological parameters viz., Soil Plant Analysis Diagnosis (SPAD), Relative water content and water use efficiency $(\mathrm{r}=0.92 * *$, $\mathrm{r}=0.91^{*}$ and $\mathrm{r}=0.86^{*}$, respectively) are significantly correlated with fodder yield per $\mathrm{kg}$ seeds. Since the amount of nitrogen given and the amount of light delivered have a significant impact on the SPAD values indicating greenness. Nitrogen is a component of chloroplast porphyrins and plays a direct role in controlling chlorophyll concentration and leaf colour. As a result, higher SPAD values and relative water content are associated with increased fodder yield. The positive relationship between water use efficiency and fodder yield per unit area is attributable to higher fodder yield per unit area with the same rate of water application to all treatments. Thus, we may conclude from this correlation analysis that plant factors have both a positive and negative relationship with fodder yield. 
Table 1: Correlation matrix of fodder maize with growth, yield, physiological and nutrient parameters as influenced by different seed rates

\begin{tabular}{|c|c|c|c|c|c|c|c|c|c|c|c|c|c|c|c|c|c|c|c|c|c|c|}
\hline SN & Parameters & 1 & 2 & 3 & 4 & 5 & 6 & 7 & 8 & 9 & 10 & 11 & 12 & 13 & 14 & 15 & 16 & 17 & 18 & 19 & 20 & 21 \\
\hline 1 & Yield per kg & 1.00 & & & & & & & & & & & & & & & & & & & & \\
\hline 2 & $\begin{array}{l}\text { Total fresh weight } \\
\text { (individual plant) }\end{array}$ & -0.54 & 1.00 & & & & & & & & & & & & & & & & & & & \\
\hline 3 & $\begin{array}{l}\text { Total fresh weight } \\
\left(\mathrm{g} \mathrm{m}^{-2}\right)\end{array}$ & $0.86^{*}$ & $\begin{array}{l}0.89 \\
*\end{array}$ & 1.00 & & & & & & & & & & & & & & & & & & \\
\hline 4 & $\begin{array}{l}\text { Total fresh weight } \\
\text { per kg of seed }\end{array}$ & $\begin{array}{l}0.95^{*} \\
*\end{array}$ & -0.49 & $0.81^{*}$ & 1.00 & & & & & & & & & & & & & & & & & \\
\hline 5 & $\begin{array}{l}\text { Total dry weight } \\
\text { (individual plant) }\end{array}$ & -0.67 & $\begin{array}{l}0.95 \\
* * \\
\end{array}$ & - $0.93 * *$ & -0.67 & 1.00 & & & & & & & & & & & & & & & & \\
\hline 6 & $\begin{array}{l}\text { Total dry weight } \\
\left(\mathrm{g} \mathrm{m}^{-2}\right)\end{array}$ & $0.82 *$ & $\begin{array}{l}0.89 \\
*\end{array}$ & $0.98^{* *}$ & 0.74 & $-0.88^{*}$ & 1.00 & & & & & & & & & & & & & & & \\
\hline 7 & $\begin{array}{l}\text { Total dry weight } \\
\text { per kg of seed }\end{array}$ & $0.86^{*}$ & -0.74 & $0.91 * *$ & 0.75 & -0.73 & $\begin{array}{l}0.96^{*} \\
* \\
\end{array}$ & 1.00 & & & & & & & & & & & & & & \\
\hline 8 & Shoot length $(\mathrm{cm})$ & $0.90^{*}$ & -0.16 & 0.59 & $0.90^{*}$ & -0.35 & 0.54 & 0.65 & 1.00 & & & & & & & & & & & & & \\
\hline 9 & Root length $(\mathrm{cm})$ & $0.85^{*}$ & -0.09 & 0.51 & $0.82^{*}$ & -0.25 & 0.48 & 0.62 & $\begin{array}{l}0.98^{*} \\
*\end{array}$ & 1.00 & & & & & & & & & & & & \\
\hline 10 & Seedling vigour & $0.84 *$ & -0.04 & 0.48 & $0.83^{*}$ & -0.22 & 0.44 & 0.58 & $\begin{array}{l}0.98^{*} \\
* \\
\end{array}$ & \begin{tabular}{|l|l|}
$0.99 *$ \\
$*$
\end{tabular} & 1.00 & & & & & & & & & & & \\
\hline 11 & WUE & $0.86^{*}$ & $\begin{array}{l}0.88 \\
*\end{array}$ & $1.00^{* *}$ & $0.82 *$ & $\overline{-} .93 * *$ & $\begin{array}{l}0.98^{*} \\
*\end{array}$ & $\begin{array}{l}0.92 * \\
*\end{array}$ & 0.59 & 0.52 & 0.49 & 1.00 & & & & & & & & & & \\
\hline 12 & RWC & $0.91 *$ & -0.56 & $0.82^{*}$ & $0.81^{*}$ & -0.61 & $0.84^{*}$ & $\begin{array}{l}0.91 * \\
*\end{array}$ & $0.83^{*}$ & $0.84^{*}$ & 0.79 & $\begin{array}{l}0.83 \\
*\end{array}$ & 1.00 & & & & & & & & & \\
\hline 13 & SPAD & $\begin{array}{l}0.92 * \\
*\end{array}$ & -0.48 & 0.79 & $\begin{array}{l}0.98^{*} \\
*\end{array}$ & -0.69 & 0.69 & 0.67 & $0.85^{*}$ & 0.76 & 0.77 & 0.79 & 0.73 & 1.00 & & & & & & & & \\
\hline 14 & $\mathrm{~N}$ content & 0.56 & 0.23 & 0.18 & 0.53 & 0.15 & 0.21 & 0.45 & 0.78 & 0.80 & $\begin{array}{l}0.82 \\
*\end{array}$ & 0.18 & 0.56 & 0.43 & 1.00 & & & & & & & \\
\hline 15 & $P$ content & 0.06 & 0.63 & -0.32 & 0.26 & 0.39 & -0.43 & -0.34 & 0.43 & 0.41 & 0.48 & -0.32 & $\overline{0} .09$ & 0.29 & 0.48 & 1.00 & & & & & & \\
\hline 16 & $\mathrm{~K}$ content & 0.34 & 0.54 & -0.13 & 0.32 & 0.43 & -0.12 & 0.10 & 0.62 & 0.64 & 0.69 & -0.13 & 0.24 & 0.27 & $0.89^{*}$ & 0.63 & \begin{tabular}{|l|}
1.00 \\
\end{tabular} & & & & & \\
\hline 17 & Crude Protein & 0.56 & 0.23 & 0.18 & 0.53 & 0.15 & 0.21 & 0.45 & 0.78 & 0.80 & $\begin{array}{l}0.82 \\
*\end{array}$ & 0.18 & 0.56 & 0.43 & $\begin{array}{l}1.00^{*} \\
*\end{array}$ & 0.48 & \begin{tabular}{|l|}
0.89 \\
$*$
\end{tabular} & 1.00 & & & & \\
\hline 18 & Crude Fibre & 0.22 & 0.58 & -0.20 & 0.28 & 0.45 & -0.21 & 0.009 & 0.60 & 0.66 & 0.69 & -0.20 & 0.25 & 0.21 & $0.84 *$ & 0.78 & \begin{tabular}{|l|}
0.83 \\
$*$ \\
\end{tabular} & $\begin{array}{l}0.84 \\
* \\
\end{array}$ & 1.00 & & & \\
\hline 19 & Total Carbohydrate & 0.16 & 0.08 & 0.06 & 0.04 & 0.21 & 0.19 & 0.39 & 0.17 & 0.18 & 0.19 & 0.05 & 0.22 & $\overline{-} .06$ & 0.65 & -0.13 & 0.55 & 0.65 & 0.32 & $\begin{array}{l}1.0 \\
0 \\
\end{array}$ & & \\
\hline 20 & AGR & 0.41 & -0.11 & 0.28 & 0.18 & 0.01 & 0.42 & 0.61 & 0.41 & 0.52 & 0.46 & 0.29 & 0.66 & 0.04 & 0.59 & -0.30 & 0.39 & 0.59 & 0.31 & $\begin{array}{l}0.6 \\
2 \\
\end{array}$ & $\begin{array}{l}1.0 \\
0 \\
\end{array}$ & \\
\hline 21 & R: S ratio & 0.18 & $\begin{array}{l}0.85 \\
*\end{array}$ & 0.61 & 0.07 & -0.66 & 0.70 & 0.60 & -0.18 & -0.20 & -0.27 & 0.61 & 0.34 & 0.03 & -0.29 & $0.85^{*}$ & -0.61 & -0.29 & $\overline{-}-62$ & $\begin{array}{l}0.1 \\
9\end{array}$ & $\begin{array}{l}0.2 \\
7\end{array}$ & $\begin{array}{l}1.0 \\
0\end{array}$ \\
\hline
\end{tabular}

$* *$ Correlation is significant at the 0.01 level (2-tailed) WUE: Water use efficiency $\left(\mathrm{kg} \mathrm{m}^{-3}\right)$

SPAD: Soil plant analysis development
*Correlation is significant at the 0.05 level (2-tailed)

RWC: Relative water content (\%)

$R: S$ ratio: Root to Shoot ratio

AGR: Absolute growth rate $\left(\mathrm{g} \mathrm{day}^{-1} \times 10^{-3}\right)$ 
This suggests that in the hydroponic approach, maize fodder production per $\mathrm{kg}$ seeds is linked to improved growth, yield, and physiological characteristics.

\section{Regression analysis}

During the study simple liner regression equation and the stepwise multiple regression equation were developed between fodder yield and growth, yield, plant physiological, nutritional, and quality parameters.

\section{Simple linear regression}

By treating fodder production per $\mathrm{kg}$ as a dependent factor $(\mathrm{Y})$ and other individual factors as independent factor $(\mathrm{X})$, simple linear coefficients (b) and a regression equation were established. Except for total fresh weight and dried weight of individual plants, all $\mathrm{b}$ values were positive (Table 2). The simple linear regression revealed a significant positive relationship between growth parameters such as shoot length, root length, seedling vigour, dry matter accumulation per $\mathrm{kg}$ seeds, total dry matter accumulation per $\mathrm{m}^{2}$, and yield parameters such as total fresh weight and fresh weight per $\mathrm{kg}$ seeds, as well as yield parameters such as total fresh weight and fresh weight per $\mathrm{kg}$ seeds. There is also a positive relationship between quality measures like nitrogen, phosphorous, potassium, crude protein, crude fibre, and total carbohydrates and physiological parameters like SPAD, water use efficiency, and relative water content. As a result, increasing the seed rate to $2.5 \mathrm{~kg} \mathrm{~m}^{-2}$ has a beneficial impact on fodder yield. Total dry matter accumulation in individual plants and fresh weight of individual plants showed a negative association, indicating lower yield with reduced seed rate. According to the coefficient of regression, a $1 \mathrm{~cm}$ increase in shoot length and $1 \mathrm{~cm}$ increase in root length will result in 0.19 and $0.17 \mathrm{~kg}$ fodder $\mathrm{kg}$ seeds sown, respectively.

The coefficient of determination $\left(\mathrm{R}^{2}\right)$ of simple liner regression between yield and growth parameters ranged between 71 to 81 per cent and yield parameters between 31 to 91 per cent. Significant positive results were obtained with physiological parameters and quality parameters (74 to 84 per cent and 20 to 31 per cent, respectively). The higher significant $\mathrm{R}^{2}$ values were obtained with SPAD $(84 \% * *)$, RWC $(83 \% * *)$ and shoot length (81 per cent*), which plays important role in determining fodder yield of maize (Table 2).

Table 2: Simple liner regression equation as influenced by different seed rates

\begin{tabular}{|c|c|c|c|c|c|}
\hline SN & $\mathbf{Y}$ & $\mathbf{X}$ & Regression values (b values) & Regression equation & $\mathbf{R}^{2}$ \\
\hline 1 & \multirow{19}{*}{ 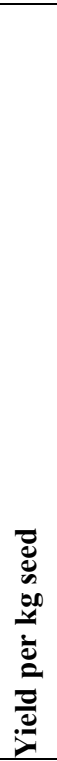 } & Total fresh weight (individual plant) & -1.05 & $6.28-1.05 \mathrm{X}$ & 0.31 \\
\hline 2 & & Total fresh weight $\left(\mathrm{g} \mathrm{m}^{-2}\right)$ & $0.00008^{* *}$ & $3.47+0.00008 \mathrm{X}$ & $0.74 * *$ \\
\hline 3 & & Total dry weight (individual plant) & -0.017 & $8.83-0.017 \mathrm{X}$ & 0.45 \\
\hline 4 & & Total dry weight $\left(\mathrm{g} \mathrm{m}^{-2}\right)$ & 0.00019 & $3.68+0.00019 \mathrm{X}$ & 0.68 \\
\hline 5 & & Total dry weight per kg of seed & $0.0011 * *$ & $2.66+0.0011 X$ & $0.74 * *$ \\
\hline 6 & & Shoot length $(\mathrm{cm})$ & $0.19 *$ & $-1.18+0.19 X$ & $0.81^{*}$ \\
\hline 7 & & Root length (cm) & $0.17 * *$ & $-0.02+0.17 \mathrm{X}$ & $0.72 * *$ \\
\hline 8 & & Seedling vigour & $0.00090 *$ & $-0.15+0.00090 \mathrm{X}$ & $0.71 *$ \\
\hline 9 & & WUE & $0.0014^{* *}$ & $3.45+0.0014 \mathrm{X}$ & $0.74 * *$ \\
\hline 10 & & RWC & $0.09 * *$ & $-3.42+0.09 \mathrm{X}$ & $0.83^{* *}$ \\
\hline 11 & & SPAD & $0.35 * *$ & $-2.37+0.35 X$ & $0.84 * *$ \\
\hline 12 & & Nitrogen $(\%)$ & 2.36 & $-0.599+2.36 \mathrm{X}$ & 0.31 \\
\hline 13 & & Phosphorus (\%) & 1.36 & $3.46+1.36 \mathrm{X}$ & 0.004 \\
\hline 14 & & Potassium (\%) & 2.31 & $2.73+2.31 X$ & 0.12 \\
\hline 15 & & Crude protein (\%) & 0.37 & $-0.59+0.37 \mathrm{X}$ & 0.31 \\
\hline 16 & & Crude fibre $(\%)$ & 0.11 & $2.92+0.11 \mathrm{X}$ & 0.05 \\
\hline 17 & & Total carbohydrate (\%) & 0.15 & $2.32+0.15 \mathrm{X}$ & 0.02 \\
\hline 18 & & AGR & 0.08 & $3.90+0.08 \mathrm{X}$ & 0.17 \\
\hline 19 & & R: S ratio & 2.17 & $3.33+2.17 \mathrm{X}$ & 0.03 \\
\hline
\end{tabular}

** Significant at the 0.01 level

WUE: Water use efficiency $\left(\mathrm{kg} \mathrm{m}^{-3}\right)$

SPAD: Soil plant analysis development

R:S ratio: Root to Shoot ratio
*Significant at the 0.05 level

RWC: Relative water content $(\%)$

AGR: Absolute growth rate $\left(\mathrm{g} \mathrm{day}^{-1} \times 10^{-3}\right)$ 
Table 3: Step wise regression equation between fodder yield and growth, yield, plant physiological, nutrient and quality parameters as influenced by different seed rate

\begin{tabular}{|l|l|l|l|l|l|l|}
\hline $\mathbf{S N}$ & Parameters & $\mathbf{R}$ & $\mathbf{R}^{2}$ & $\begin{array}{l}\text { Adjusted } \\
\mathbf{R}^{2}\end{array}$ & $\begin{array}{l}\text { Standard } \\
\text { error }\end{array}$ & Regression equation \\
\hline 1 & Growth & $0.99^{*}$ & $0.99^{*}$ & $0.99^{*}$ & 0.014 & $-3.49+0.936 \mathrm{Xa}_{1}+0.290 \mathrm{Xa}_{2}-0.005 \mathrm{Xa}_{3}-0.00006 \mathrm{Xa}_{4}$ \\
\hline 2 & Yield & $0.99^{* *}$ & $0.99^{* *}$ & $0.49^{* *}$ & 0.008 & $0.3060-0.0005 \mathrm{Xb}_{1}-0.00074 \mathrm{Xb}_{2}+\mathrm{Xb}_{3}+0.0012 \mathrm{Xb}_{4}$ \\
\hline 3 & Plant physiological & $0.99^{*}$ & $0.99^{*}$ & $0.99^{*}$ & 0.019 & $-4.03-0.00036 \mathrm{Xc}_{1}+0.037 \mathrm{Xc}_{2}+0.316 \mathrm{Xc}_{3}$ \\
\hline 4 & Nutrient uptake & $0.68^{*}$ & $0.46^{*}$ & $-0.32^{*}$ & 0.246 & $-4.72+5.13 \mathrm{Xd}_{1}+4.6 \mathrm{Xd}_{2}-6.02 \mathrm{Xd}_{3}$ \\
\hline 5 & Quality & $0.96^{*}$ & $0.92^{*}$ & $0.82^{*}$ & 0.09 & $51.43+1.61 \mathrm{Xe}_{1}-0.69 \mathrm{Xe}_{2}-0.97 \mathrm{Xe}_{3}$ \\
\hline
\end{tabular}

** Significant at the 0.01 level

$\mathrm{Xa}_{1} \quad=\quad$ Shoot length $(\mathrm{cm})$

$\mathrm{Xa}_{2} \quad=\quad$ Root length $(\mathrm{cm})$

$\mathrm{Xa}_{3}=$ Seedling vigour

$\mathrm{Xa}_{4} \quad=\quad$ Dry matter accumulation $\left(\mathrm{g} \mathrm{kg}^{-1}\right.$ seed $)$

$\mathbf{X b}_{1} \quad=\quad$ Fresh weight of shoot $\left(\mathrm{g} \mathrm{kg}^{-1}\right.$ seed $)$

$\mathbf{X b}_{2}=$ Fresh weight of $\operatorname{root}\left(\mathrm{g} \mathrm{kg}^{-1}\right.$ seed $)$

$\mathbf{X b}_{3} \quad=\quad$ Fresh weight of seed $\left(\mathrm{g} \mathrm{kg}^{-1}\right.$ seed $)$

$\mathbf{X b}_{4} \quad=\quad$ Total fresh weight $\left(\mathrm{g} \mathrm{kg}^{-1}\right.$ seed $)$
*Significant at the 0.05 level

$\begin{array}{lll}\mathbf{X c}_{1} & = & \text { SPAD } \\ \mathbf{X c}_{2} & = & \mathbf{R W C}(\%) \\ \mathbf{X c}_{3} & = & \text { WUE }\left(\mathrm{kg} \mathrm{m}^{-3}\right) \\ \mathbf{X d}_{1} & = & \text { Nitrogen }(\%) \\ \mathbf{X d}_{2} & = & \text { Phosphorous }(\%) \\ \mathbf{X d}_{3} & = & \text { Potassium }(\%) \\ \mathbf{X e}_{1} & = & \text { Crude protein }(\%) \\ \mathbf{X e}_{2} & = & \text { Crude fibre }(\%)\end{array}$

\section{Step wise multiple regression}

Stepwise multiple regressions indicate a substantial positive association between fodder yield and growth, yield, plant physiological, nutritional, and quality parameters. The regression coefficient of determination $\left(\mathrm{R}^{2}\right)$ between yield and growth, yield was 0.99 (Table 3) shows that the yield is 99 percent dependent on these parameters. Table 3 shows the stepwise multiple regression equations for growth, yield attributes, plant physiological parameters, nutrient uptake, and quality parameters. Hence, when sown with varying seed rates, these equations demonstrate a significant impact of different parameters on fodder yield.

Experiment 2: To calibrate nutrition for higher yield and quality of hydroponic fodder maize

The experiment was conducted with 9 treatments and are repeated three times. For calibrating nutrition for hydroponically produced fodder maize, the best treatment in the seed rate experiment $\left(2.50 \mathrm{~kg} \mathrm{~m}^{-2}\right)$ was chosen. The two combined sprays of urea and MOP each @ 1\% at 3 and 10 DAS resulted in significantly higher maize fodder output (13.93 $\mathrm{kg} \mathrm{m}^{-2}$ ) than the control (11.53 $\mathrm{kg} \mathrm{m}^{-2}$ ) (Figure 2). Higher fodder yield of maize with combined spray of urea and MOP each @
1 percent at 3 and 10 DAS is mainly due to significantly higher fresh weight of shoot, root and seed, higher dry matter accumulation at different growth stage and their partitioning into different parts of the crop viz., shoot and root. Increased photosynthetic activity, which is primarily regulated by nitrogen and potassium nutrition and synchronized supply according to crop needs, may be ascribed to higher dry matter accumulation and translocation into different regions. In line with the findings, Mutum Lamnganbi and Surve (2017b) also stated that application of foliar nutrients increased fodder yield of white and yellow maize significantly compared to control. Gunasekaran et al., 2017 also stated that application of nutrient source like vermiwash and urea increased the biomass yield as compared to no spray treatment.

\section{Correlation studies}

Karl Pearson's correlation coefficient was worked out between fodder yield with growth, yield, physiological and nutrient parameters as influenced by foliar nutrition under hydroponics is presented in Table 4. The results revealed that significant positive correlation was observed between fodder yield with shoot length $(\mathrm{r}=0.90 * *)$, root length 


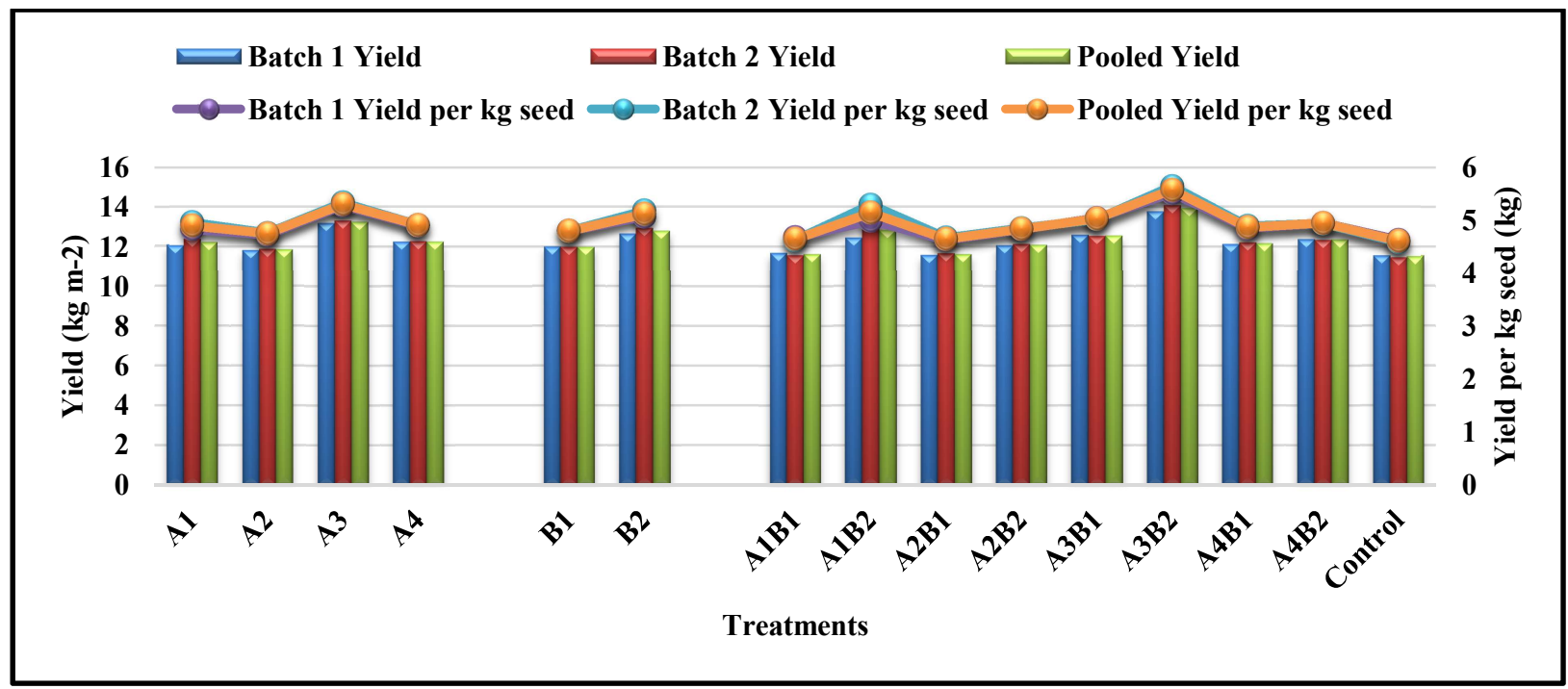

Figure 2: Yield and yield per kg seed of fodder maize as influenced by foliar nutrition under hydroponics

$\mathbf{A}_{1}$ : Urea@ $1 \%$

$A_{2}$ :MOP@ $1 \%$

$A_{3}$ : Urea@1\% and MOP@1\%

$A_{4}: 19: 19: 19 @ 1 \%$

$\left(\mathrm{r}=0.74^{* *}\right)$, seedling vigour $\left(\mathrm{r}=0.86^{* *}\right)$ and dry matter accumulation $\left(\mathrm{r}=0.97^{* *}\right)$ with application of two combined sprays of urea and MOP each @ 1 per cent at 3 and 10 DAS. This means that increasing the value of one of these parameters causes the value of the parameter with which it is substantially associated to increase (Malik et al., 2011). Indeed, the positive correlation between this measure and fodder yield is an essential signal. The positive correlation is due to application of nitrogen and potassium boosted meristematic activity in terms of increased cell division and elongation, resulting in enhanced shoot and root length. As a result, nitrogen is involved in protein synthesis and the translocation of growth hormones, which act as growth and development stimulants. In addition, compared to the control, the plant's greater uptake of nutrients and effective utilisation allowed it to produce higher growth. Increases in shoot, root, and dry matter accumulation will improve fodder yield proportionately, according to the significant positive association. This is in line with Mutum Lamnganbi and Surve (2017a), they stated that shoot length increased in 19:19:19@ 0.5 per cent as compared to control. It also shows showed positive correlation between fodder yield and total fresh weight of fodder $\left(\mathrm{r}=0.965^{* *}\right)$, individual fresh weight of plant $\left(\mathrm{r}=0.95^{* *}\right)$ and individual dry
$\mathrm{B}_{1}$ : One spray at 6 DAS

$B_{2}$ : Two spray at $3 \& 10$ DAS weight of plant $\left(\mathrm{r}=0.97^{* *}\right)$. The physiological parameters like SPAD $\left(\mathrm{r}=0.78^{* *}\right)$ and WUE $\left(\mathrm{r}=1.00^{* *}\right)$ are also significantly correlated with fodder yield. This means that a lack of development in each parameter that is positively connected with yield will have a negative impact on fodder productivity. The higher dry matter accumulation in different plant parts is mainly due to efficient availability of nutrients supplied by repetitive spray at critical nutrient demanding stage, which might result in higher dry matter accumulation and their distribution. This is in conformity with Mutum Lamnganbi and Surve (2017b). This means that a lack of development in each parameter that is positively connected with yield will have a negative impact on crop productivity.

Hence the significant positive correlation coefficient of different parameters indicates that fodder yield is dependent on nutrient supply and nutrient schedule time.

\section{Regression analysis}

\section{Simple linear regression}

The simple linear coefficients (b) and regression equation were developed by keeping fodder yield $(\mathrm{kg} \mathrm{m})^{-2}$ as dependent factor $(\mathrm{Y})$ and other individual factors as independent factors (X). All of the parameters under consideration had positive $b$ values. As a result, applying two combined sprays 
Table 4: Correlation matrix of fodder maize with growth, yield, physiological and nutrient parameters as influenced by foliar nutrition under hydroponics

\begin{tabular}{|c|c|c|c|c|c|c|c|c|c|c|c|c|c|c|c|c|c|c|c|c|c|}
\hline $\begin{array}{l}\mathbf{S} \\
\mathbf{N}\end{array}$ & Parameters & 1 & 2 & 3 & 4 & 5 & 6 & 7 & 8 & 9 & 10 & 11 & 12 & 13 & 14 & 15 & 16 & 17 & 18 & 19 & 20 \\
\hline 1 & Yield & 1.00 & & & & & & & & & & & & & & & & & & & \\
\hline 2 & Yield per kg seed & $\begin{array}{l}1.00^{*} \\
*\end{array}$ & 1.00 & & & & & & & & & & & & & & & & & & \\
\hline 3 & $\begin{array}{l}\text { Fresh weight } \\
\text { (individual plant) }\end{array}$ & $\begin{array}{l}0.95^{*} \\
*\end{array}$ & $\begin{array}{l}0.95^{*} \\
*\end{array}$ & 1.00 & & & & & & & & & & & & & & & & & \\
\hline 4 & $\begin{array}{l}\text { Fresh weight }(\mathrm{g} \\
\left.\mathrm{m}^{-2}\right)\end{array}$ & $\begin{array}{l}0.96^{*} \\
*\end{array}$ & $\begin{array}{l}0.96^{*} \\
*\end{array}$ & $\begin{array}{l}0.99 * \\
*\end{array}$ & 1.00 & & & & & & & & & & & & & & & & \\
\hline 5 & $\begin{array}{l}\text { Dry weight } \\
\text { (individual plant) }\end{array}$ & $\begin{array}{l}0.97 * \\
*\end{array}$ & $\begin{array}{l}0.97^{*} \\
*\end{array}$ & $\begin{array}{l}0.94 * \\
*\end{array}$ & $\begin{array}{l}0.97^{*} \\
*\end{array}$ & 1.00 & & & & & & & & & & & & & & & \\
\hline 6 & $\begin{array}{l}\text { Dry weight }\left(\mathrm{g} \mathrm{m}^{-}\right. \\
\left.{ }^{2}\right)\end{array}$ & $\begin{array}{l}0.97^{*} \\
*\end{array}$ & $\begin{array}{l}0.97^{*} \\
*\end{array}$ & $\begin{array}{l}0.94 * \\
*\end{array}$ & $\begin{array}{l}0.97^{*} \\
*\end{array}$ & $1.0^{* *}$ & 1.00 & & & & & & & & & & & & & & \\
\hline 7 & $\begin{array}{ll}\begin{array}{l}\text { Shoot length } \\
(\mathrm{cm})\end{array} \\
\end{array}$ & $\begin{array}{l}0.90^{*} \\
* \\
\end{array}$ & $\begin{array}{l}0.90^{*} \\
*\end{array}$ & $\begin{array}{l}0.97^{*} \\
*\end{array}$ & $\begin{array}{l}0.97^{*} \\
*\end{array}$ & $\begin{array}{l}0.92 * \\
*\end{array}$ & $\begin{array}{l}0.92 * \\
*\end{array}$ & 1.00 & & & & & & & & & & & & & \\
\hline 8 & Root length $(\mathrm{cm})$ & $0.74 *$ & $0.74 *$ & $0.80^{*}$ & $0.80^{*}$ & $0.79 *$ & $0.79^{*}$ & $0.79^{*}$ & 1.00 & & & & & & & & & & & & \\
\hline 9 & Seedling vigour & $\begin{array}{l}0.86^{*} \\
*\end{array}$ & $\begin{array}{l}0.86^{*} \\
*\end{array}$ & $\begin{array}{l}0.94 * \\
*\end{array}$ & $\begin{array}{l}0.94 * \\
*\end{array}$ & $\begin{array}{l}0.90^{*} \\
*\end{array}$ & $\begin{array}{l}0.90^{*} \\
*\end{array}$ & $\begin{array}{l}0.95^{*} \\
*\end{array}$ & $\begin{array}{l}0.93 * \\
*\end{array}$ & 1.00 & & & & & & & & & & & \\
\hline 10 & SPAD & $0.78^{*}$ & $0.77^{*}$ & $0.76^{*}$ & $0.79 *$ & $0.80^{*}$ & $0.80^{*}$ & $0.76^{*}$ & 0.61 & 0.69 & 1.00 & & & & & & & & & & \\
\hline 11 & RWC & 0.49 & 0.50 & 0.45 & 0.47 & 0.50 & 0.50 & 0.41 & 0.49 & 0.51 & -0.05 & 1.00 & & & & & & & & & \\
\hline 12 & WUE & $\begin{array}{l}1.00^{*} \\
*\end{array}$ & $\begin{array}{l}1.00^{*} \\
*\end{array}$ & $\begin{array}{l}0.95 * \\
*\end{array}$ & $\begin{array}{l}0.96^{*} \\
*\end{array}$ & $\begin{array}{l}0.97 * \\
*\end{array}$ & $\begin{array}{l}0.97^{*} \\
*\end{array}$ & $\begin{array}{l}0.90^{*} \\
*\end{array}$ & $0.74 *$ & $\begin{array}{l}0.86^{*} \\
*\end{array}$ & $0.78^{*}$ & 0.50 & 1.00 & & & & & & & & \\
\hline 13 & $\mathrm{~N}$ content $(\%)$ & $\begin{array}{l}0.92 * \\
*\end{array}$ & $\begin{array}{l}0.92 * \\
*\end{array}$ & $\begin{array}{l}0.90^{*} \\
*\end{array}$ & $\begin{array}{l}0.92 * \\
*\end{array}$ & $\begin{array}{l}0.88^{*} \\
*\end{array}$ & $\begin{array}{l}0.88^{*} \\
*\end{array}$ & $\begin{array}{l}0.92 * \\
*\end{array}$ & 0.68 & $\begin{array}{l}0.83^{*} \\
*\end{array}$ & $\begin{array}{l}0.85^{*} \\
*\end{array}$ & 0.27 & $\begin{array}{l}0.92 * \\
*\end{array}$ & 1.00 & & & & & & & \\
\hline 14 & $\mathrm{P}$ content $(\%)$ & 0.17 & 0.18 & 0.29 & 0.25 & 0.30 & 0.30 & 0.19 & 0.41 & 0.31 & 0.21 & 0.04 & 0.17 & -0.04 & 1.00 & & & & & & \\
\hline 15 & $\mathrm{~K}$ content $(\%)$ & 0.46 & 0.43 & 0.47 & 0.47 & 0.53 & 0.53 & 0.42 & 0.54 & 0.54 & -0.05 & $\begin{array}{l}0.90^{*} \\
*\end{array}$ & 0.46 & 0.18 & 0.39 & 1.00 & & & & & \\
\hline 16 & Crude protein & $\begin{array}{l}0.92 * \\
*\end{array}$ & $\begin{array}{l}0.92 * \\
*\end{array}$ & $\begin{array}{l}0.91 * \\
*\end{array}$ & $\begin{array}{l}0.92 * \\
*\end{array}$ & $\begin{array}{l}0.88^{*} \\
*\end{array}$ & $\begin{array}{l}0.88^{*} \\
*\end{array}$ & $\begin{array}{l}0.92^{*} \\
*\end{array}$ & 0.68 & $\begin{array}{l}0.83^{*} \\
*\end{array}$ & $\begin{array}{l}0.85^{*} \\
*\end{array}$ & 0.27 & $\begin{array}{l}0.92 * \\
*\end{array}$ & $1.0^{* *}$ & 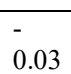 & 0.18 & 1.00 & & & & \\
\hline 17 & Crude fibre & $0.77 *$ & $0.77^{*}$ & $0.75^{*}$ & $0.78^{*}$ & $0.82^{*}$ & $0.82^{*}$ & 0.70 & $0.72 *$ & $0.77^{*}$ & 0.37 & $\begin{array}{l}0.87^{*} \\
*\end{array}$ & $0.77 *$ & 0.54 & 0.35 & $\begin{array}{l}0.87^{*} \\
*\end{array}$ & 0.54 & $\begin{array}{l}1.0 \\
0\end{array}$ & & & \\
\hline 18 & $\begin{array}{l}\text { Total } \\
\text { carbohydrates }\end{array}$ & $\begin{array}{l}0.90^{*} \\
*\end{array}$ & $\begin{array}{l}0.90^{*} \\
*\end{array}$ & $\begin{array}{l}0.90^{*} \\
*\end{array}$ & $\begin{array}{l}0.92 * \\
*\end{array}$ & $\begin{array}{l}0.87^{*} \\
*\end{array}$ & $\begin{array}{l}0.87^{*} \\
*\end{array}$ & $\begin{array}{l}0.90^{*} \\
*\end{array}$ & $0.78^{*}$ & $\begin{array}{l}0.88^{*} \\
*\end{array}$ & $\begin{array}{l}0.83^{*} \\
*\end{array}$ & 0.36 & $\begin{array}{l}0.90^{*} \\
*\end{array}$ & $\begin{array}{l}0.95^{*} \\
*\end{array}$ & 0.01 & 0.23 & $\begin{array}{l}0.95^{*} \\
*\end{array}$ & $\begin{array}{l}0.6 \\
2\end{array}$ & 1.00 & & \\
\hline 19 & AGR & 0.65 & 0.65 & 0.70 & $0.72 *$ & $0.72 *$ & $0.72 *$ & $0.76^{*}$ & $\begin{array}{l}0.92 * \\
*\end{array}$ & $\begin{array}{l}0.86^{*} \\
*\end{array}$ & 0.70 & 0.25 & 0.65 & $0.71 *$ & 0.24 & 0.30 & $0.71^{*}$ & $\begin{array}{l}0.5 \\
1\end{array}$ & $\begin{array}{l}0.77 \\
*\end{array}$ & $\begin{array}{l}1.0 \\
0\end{array}$ & \\
\hline 20 & $\mathrm{R}: \mathrm{S}$ ratio & 0.44 & 0.45 & 0.66 & 0.59 & 0.41 & 0.41 & 0.66 & 0.39 & 0.59 & 0.34 & 0.16 & 0.44 & 0.51 & 0.18 & 0.15 & 0.51 & $\begin{array}{l}0.3 \\
1\end{array}$ & 0.55 & $\begin{array}{l}0.2 \\
6\end{array}$ & $\begin{array}{l}1.0 \\
0\end{array}$ \\
\hline
\end{tabular}

** Correlation is significant at the 0.01 level (2-tailed) WUE: Water use efficiency $\left(\mathrm{kg} \mathrm{m}^{-3}\right)$

SPAD: Soil plant analysis development
*Correlation is significant at the 0.05 level (2-tailed)

RWC: Relative water content (\%)

R:S ratio: Root to Shoot ratio

AGR: Absolute growth rate $\left(\mathrm{g} \mathrm{day}^{-1} \times 10^{-3}\right)$ 
Table 5: Simple linear regression equation as influenced by foliar nutrition under hydroponics

\begin{tabular}{|c|c|c|c|c|c|}
\hline SN & $\mathbf{Y}$ & $\mathbf{X}$ & Regression values (b values) & Regression equation & $\mathbf{R}^{2}$ \\
\hline 1 & \multirow{18}{*}{ 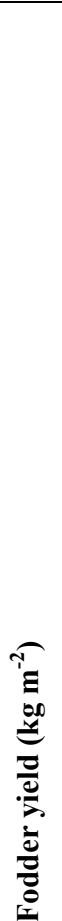 } & Total fresh weight (individual plant) & $4.5^{* *}$ & $1.47+4.58 \mathrm{x}$ & $0.89 * *$ \\
\hline 2 & & Total fresh weight $\left(\mathrm{g} \mathrm{m}^{-2}\right)$ & $0.001 * *$ & $-0.34+0.0010 \mathrm{X}$ & $0.93 * *$ \\
\hline 3 & & Total dry weight (individual plant) & $0.05 * *$ & $-6.53+0.05 X$ & $0.94 * *$ \\
\hline 4 & & Total dry weight $\left(\mathrm{g} \mathrm{m}^{-2}\right)$ & $0.04^{*}$ & $-6.53+0.004 X$ & $0.94 *$ \\
\hline 5 & & Shoot length (cm) & $0.47 *$ & $-2.42+0.47 \mathrm{X}$ & $0.81 *$ \\
\hline 6 & & Root length (cm) & $0.49 *$ & $-1.292+0.49 X$ & $0.56^{*}$ \\
\hline 7 & & Seedling vigour & $0.002 * *$ & $-2.59+0.002 X$ & $0.74 * *$ \\
\hline 8 & & WUE & 0.018 & $8.81 \times 10^{-15}+0.018 \mathrm{X}$ & 1.00 \\
\hline 9 & & RWC & $0.13^{*}$ & $1.89+0.13 x$ & $0.25^{*}$ \\
\hline 10 & & SPAD & $0.26^{* *}$ & $6.79+0.26 \mathrm{X}$ & $0.60 * *$ \\
\hline 11 & & Nitrogen $(\%)$ & $2.46^{*}$ & $6.73+2.46 \mathrm{X}$ & $0.85^{*}$ \\
\hline 12 & & Phosphorus (\%) & 1.32 & $11.73+1.32 X$ & 0.029 \\
\hline 13 & & Potassium $(\%)$ & $2.84 *$ & $9.95+2.84 X$ & $0.20 *$ \\
\hline 14 & & Crude protein $(\%)$ & $0.39 *$ & $6.73+0.39 X$ & $0.85^{*}$ \\
\hline 15 & & Crude fibre (\%) & $0.57 *$ & $5.36+0.57 X$ & 0.59 \\
\hline 16 & & Total carbohydrate (\%) & $0.31 *$ & $-7.76+0.31 X$ & $0.81 *$ \\
\hline 17 & & AGR & $0.26^{*}$ & $11.34+0.26 \mathrm{X}$ & $0.43^{*}$ \\
\hline 18 & & $\mathrm{R}: \mathrm{S}$ ratio & $32.75^{*}$ & $-4.16+32.75 X$ & $0.22 *$ \\
\hline
\end{tabular}

** Significant at the 0.01 level

WUE: Water use efficiency $\left(\mathrm{kg} \mathrm{m}^{-3}\right)$

SPAD: Soil plant analysis development
*Significant at the 0.05 level

RWC: Relative water content (\%)

AGR: Absolute growth rate $\left(\mathrm{g} \mathrm{day}^{-1} \times 10^{-3}\right)$

Table 6: Step wise multiple regression equation between fodder yield and growth, yield, plant physiological, nutrient and quality parameters as influenced by foliar nutrition under hydroponics.

\begin{tabular}{|l|l|l|l|l|l|l|}
\hline $\mathbf{S N}$ & Parameters & $\mathbf{R}$ & $\mathbf{R}^{2}$ & Adjusted $\mathbf{R}^{2}$ & Standard error & Regression equation \\
\hline 1 & Growth & $0.97^{*}$ & $0.95^{*}$ & $0.90^{*}$ & 0.17 & $-7.05+0.47 \mathrm{Xa}_{1}+0.36 \mathrm{Xa}_{2}-0.004 \mathrm{Xa}_{3}+0.0038 \mathrm{Xa}_{4}$ \\
\hline 2 & Yield & $0.98^{*}$ & $0.96^{*}$ & $0.94^{*}$ & 0.17 & $-4.91-0.0014 \mathrm{Xb}_{1}+0 \mathrm{Xb}_{2}+0.00099 \mathrm{Xb}_{3}+0.0019 \mathrm{Xb}_{4}$ \\
\hline 3 & Plant physiological & $0.95^{*}$ & $0.90^{*}$ & $0.86^{*}$ & 0.27 & $-4.844+2.73 \mathrm{Xc}_{1}+0.14 \mathrm{Xc}_{2}$ \\
\hline 4 & Nutrient uptake & 0.97 & 0.95 & 0.92 & 0.21 & $5.22+2.34 \mathrm{Xd}_{1}+0.77 \mathrm{Xd}_{2}+1.66 \mathrm{Xd}_{3}$ \\
\hline 5 & Quality & $0.98^{*}$ & $0.96^{*}$ & $0.93^{*}$ & 0.19 & $8.066+0.38 \mathrm{Xe}_{1}+0.304 \mathrm{Xe}_{2}-0.077 \mathrm{Xe}_{3}$ \\
\hline
\end{tabular}

$\begin{array}{lll}* * \text { Significant at the } 0.01 \text { level } \\ \mathbf{X a}_{1} & = & \text { Shoot length }(\mathrm{cm}) \\ \mathbf{X a}_{2} & = & \text { Root length }(\mathrm{cm}) \\ \mathbf{X a}_{3} & = & \text { seedling vigour } \\ \mathbf{X a}_{4} & = & \text { Dry matter accumulation }\left(\mathrm{g} \mathrm{m}^{-2}\right) \\ \mathbf{X b}_{1} & = & \text { Fresh weight of shoot }\left(\mathrm{g} \mathrm{m}^{-2}\right) \\ \mathbf{X b}_{2} & = & \text { Fresh weight of } \operatorname{root}\left(\mathrm{g} \mathrm{m}^{-2}\right) \\ \mathbf{X b}_{3} & = & \text { Fresh weight of seed }\left(\mathrm{g} \mathrm{m}^{-2}\right) \\ \mathbf{X b}_{4} & = & \text { Total fresh weight }\left(\mathrm{g} \mathrm{m}^{-2}\right)\end{array}$

*Significant at the 0.05 level

$\begin{array}{lll}\mathbf{X c}_{1} & = & \text { SPAD } \\ \mathbf{X c}_{2} & = & \mathbf{R W C}(\%) \\ \mathbf{X d}_{1} & = & \text { Nitrogen }(\%) \\ \mathbf{X d}_{2} & = & \text { Phosphorous }(\%) \\ \mathbf{X d}_{3} & = & \text { Potassium }(\%) \\ \mathbf{X e}_{1} & = & \text { Crude protein }(\%) \\ \mathbf{X e}_{2} & = & \text { Crude fibre }(\%) \\ \mathbf{X e}_{3} & = & \text { Total carbohydrate }(\%)\end{array}$


of urea and MOP at $1 \%$ each at 3 and 10 DAS will boost independent aspects such as growth, yield, physiological, nutrient uptake, and quality parameters, hence increasing maize fodder yield (Table 5). The coefficient of determination $\left(\mathrm{R}^{2}\right)$ of simple linear regression between yield and growth parameters ranged between 56 to 94 per cent and yield parameters was 89 to 93 per cent indicating the extent of dependability of yield on growth (56$94 \%$ ) and yield (89-93\%) parameter

\section{Stepwise multiple regression}

A significant positive association is shown in stepwise multiple regressions between fodder yield and growth, yield, plant physiological, nutritional and quality indicators. Regression coefficients of determination $\left(\mathrm{R}^{2}\right)$ between yield and growth and yield parameters were 95 and 96 percent, respectively. The separate stepwise regression equations were developed to know the effect combined effect of different parameters on dependent factor (Fodder yield). Here application of of two combined sprays of urea and MOP each (a) 1 per cent at 3 and 10 DAS has resulted in higher coefficient of determination (Table 6). According to these studies, increasing shoot length, root length, SPAD, relative water content, nitrogen content, phosphorus content, and potassium content by one unit will increase fodder yield by $0.47,0.49$, $0.26,0.13,2.46,1.32$, and $2.84 \mathrm{~kg} \mathrm{~m}^{-2}$, respectively,

\section{References}

Al Ajmi, A., Salih, A., Kadhim, I., \& Othman, Y. (2009). Yield and water use efficiency of barley fodder produced under hydroponic system in GCC countries using tertiary treated sewage effluents. Journal of Phytology, 1(5): 342-348.

Anonymous (2017). Basic animal husbandry statistics. Department of Animal Husbandry, Dairying and Fisheries, Ministry of Agriculture, Govt. of India, Krishna Bhawan, New Delhi. Pp. 1-152.

AOAC (2000). Official Methods of Analysis. $17^{\text {th }}$ Ed: Association of Official Analytical Chemists, Washington, DC, USA.

Draper, N. R., \& Smith, H. H. (1998). Applied regression analysis. John Wiley and Sons. Inc. New USA. Pp. 58-72

El-Morsy A. T., Abul-Soud, M., \& Emam, M. S. A. (2013). Localized hydroponic green forage technology as a climate change adaptation under Egyptian conditions. Research Journal of Agriculture and Biological Sciences, 9(6):341350 . when applied with two combined sprays of urea and MOP each@1\% at 3 and 10 DAS.

\section{Conclusion}

When maize fodder cultivated hydroponically, it was observed that applying two combined sprays of urea and MOP each at $1 \%$ at 3 and 10 DAS with $2.5 \mathrm{~kg} \mathrm{~m}^{-2}$ is a better agro-technique for increasing yield and quality of fodder. The relationship between maize growth, yield and physiological characteristics with fodder production was mirrored in correlation analysis, where they were favorably connected with fodder maize yield. Because the proposed prediction equations have a high coefficient of determination and a low standard error, they were accurate. Independent factors have a significant impact on maize fodder yield, as shown by simple and multiple regressions. Higher growth, yield, and physiological characteristics are necessary to improve maize fodder yield, according to the regression equations generated. As a result, the above-mentioned nutrition will boost independent elements in order to obtain the desired fodder output.

\section{Acknowledgement}

The authors are thankful to AICRP on Dryland Agriculture, University of Agricultural Sciences, GKVK, Bangalore for providing all facilities to conduct the experiment.

Gomez, K. A., \& Gomez, A. (1984). Statistical procedures for agricultural research. $2^{\text {nd }}$ Edition, John Willey and Sons, Inc. New York, USA. Pp: 234-237.

Gunasekaran, S., Bandeswaran, C., \& Valli, C. (2017). Effect of different nutrient solutions on the biomass yield and nutritive value of low cost hydroponic maize. Indian Journal of Animal Science, 87(11): 1418-1419.

IBM Corp (2020). IBM SPSS Statistics for Windows, Version 27.0. Armonk, NY: IBM Corp

Lorenz, K. (1980). Cereal sprouts: composition, nutritive value, food applications. Critical Reviews in Food Science and Nutrition, 13(4): 353-385.

Malik, M. F. A., Ashraf, M., Qureshi, A. S., \& Khan, M. R. (2011). Investigation and comparison of some morphological traits of the soybean populations using cluster analysis. Pakistan. Journal of Botany. 43(2): 12491255 . 
Massantini, F., \& Magnani, G. (1980). Hydroponic fodder growing: Use of cleaner separated grain. In: Fifth Inter. Cong. Soilless Culture. Istituto di Agronomia, Pisa (Italy).

Mutum Lamnganbi \& Surve, U. S. (2017a). Biomass yield and water productivity of different hydroponic fodder crops. Journal PharmacognosyPhyto-Chemistry, 6(5): 1297-1300.

Mutum Lamnganbi \& Surve, U. S. (2017b). Biological parameter and quality factor (ADF, NDF) of hydroponics under the influence of foliar spray. International Journal of Botany Studies, 2(6); 176-179.

Naik, P. K., Dhuri, R. B., Swain, B. K., \& Singh, N. P. (2012). Nutrient changes with the growth of hydroponics fodder maize. Indian Journal of Animal Nutrition, 29:161-163.
Naik, P. K., Dhuri, R. B., Swain, B. K., \& Singh, N. P. (2013). Water management for green fodder production as livestock feed in Goa. In: Abstracts of International Conference on 'Water Management for Climate Resilient Agriculture' held at Jalgaon, Maharashtra, India, May 2831, Pp. 126-127.

Naik, P. K., Swain, B. K., Chakurkar, E. B., \& Singh, N. P. (2017). Effect of seed rate on yield and proximate constituents of different parts of hydroponics maize fodder. Indian Journal of Animal Sciences, 87(1): 109-112.

Sendecor, G. W., \& Cochran, W. G. (1989). Statistical Methods, Eighth Edition, Iowa State University Press 